\title{
Active faulting and transpression tectonics along the plate boundary in North Africa
}

\author{
Mustapha Meghraoui ${ }^{1, \star}$, Silvia Pondrelli ${ }^{2}$ \\ ${ }^{1}$ Institut de Physique du Globe de Strasbourg (UMR 7516), Strasbourg, France \\ ${ }^{2}$ Istituto Nazionale di Geofisica e Volcanologia, Sezione di Bologna, Bologna, Italy
}

\author{
Article history \\ Received February 22, 2011; accepted June 4, 2012. \\ Subject classification: \\ Active tectonics, Tell Atlas, North Africa, Plate boundary, Transpression.
}

\begin{abstract}
We present a synthesis of the active tectonics of the northern Atlas Mountains, and suggest a kinematic model of transpression and block rotation that illustrates the mechanics of this section of the Africa-Eurasia plate boundary. Neotectonic structures and significant shallow seismicity (with $M w>5.0)$ indicate that coeval E-W-trending, right-lateral faulting and NE-SW, thrust-related folding result from oblique convergence at the plate boundary, which forms a transpressional system. The strain distribution obtained from fault-fold structures and P axes of focal mechanism solutions, and the geodetic (NUVEL-1 and GPS) convergence show that the shortening and convergence directions are not coaxial. The transpressional strain is partitioned along the strike and the quantitative description of the displacement field yields a compression-to-transcurrence ratio varying from 33\% near Gibraltar, to 50\% along the Tunisian Atlas. Shortening directions oriented NNE and NNW for the Pliocene and Quaternary, respectively, and the $S$ shape of the Quaternary anticline axes, are in agreement with the $2.24^{\circ}$ / Myr to $3.9^{\circ} /$ Myr modeled clockwise rotation of the small tectonic blocks and with the paleomagnetic data. The convergence between Africa and Eurasia is absorbed along the Atlas Mountains at the upper crustal level, by means of thrusting above decollement systems, which are controlled by subdued transcurrent faults. The Tell Atlas of northwest Algeria, which has experienced numerous large earthquakes with respect to the other regions, is interpreted as a restraining bend that localizes the strain distribution along the plate boundary.
\end{abstract}

\section{Introduction}

Along the Gibraltar-Sicily section, the Atlas Mountains are among the most active zones in the Mediterranean region, due to the Africa-Eurasia plate convergence (Figure 1). Large and moderate-sized shallow seismic events have been recorded over the last few decades along this plate boundary, with the largest being the October 10, 1980, El Asnam Ms 7.3 earthquake that was associated with a NWdipping, emerging thrust fault [Philip and Meghraoui 1983, Yielding et al. 1989]. The next largest events are the Boumerdes (Algeria) seismic sequence, which started with a Mw 6.8 event in May 2003 [Meghraoui et al. 2004, Braunmiller and Bernardi 2005], and the Al Hoceima (Morocco) Mw 6.4 event in 2004 [Stich et al. 2005, Cakir et al. 2006] (Figure 2a). The thrust-and-fold belts of North Africa appear, however, as a zone of diffuse deformation, with no clear interplate limit striking across the Alboran Sea and the Rif and Tell Atlas Mountains [Grimison and Chen 1986, Serpelloni et al. 2007]. The plate boundary is often indicated as an E-W straight line parallel to the Mediterranean coast, or drawn along the foreland-hinterland limit of the Tertiary fold-and-thrust belt, or inferred from hypothetical tectonic blocks. This is probably due to the low level of seismicity associated with the relatively low convergence rate (3 to $6 \mathrm{~mm} / \mathrm{yr}$ ) [McKenzie 1972, Buforn et al. 2004, Nocquet and Calais 2004], and to the complex tectonic pattern of the Tertiary contractional orogen [Frizon de Lamotte et al. 2000, Faccenna et al. 2004]. Recent models using new datasets from bathymetry [Zitellini et al. 2009] and 65 continuous global positioning system (GPS) stations [Koulali et al. 2011] have provided new insights along the plate boundary. However, the link between the late Quaternary tectonics and present-day active deformation remains poorly constrained, and a conceptual kinematic model is needed to better explain the transpressive tectonics [Morel and Meghraoui 1996].

The counter-clockwise rotation of Africa with respect to Eurasia obtained from global models implies an oblique convergence along the western section of North Africa, and shows an increasing eastward rate of $3 \mathrm{~mm} / \mathrm{yr}$ to $5 \mathrm{~mm} / \mathrm{yr}$ (NUVEL-1 plate tectonic model) [DeMets et al. 1994]. This depends on the modeling configuration of the global plate motion [DeMets et al. 1994], the tectonic geodesy models [Nocquet and Calais 2004], the GPS measurements [McClusky et al. 2003, D'Agostino and Selvaggi 2004, Sella et al. 2002], or on the combination of various data [Serpelloni et al. 2007]. Recently acquired GPS data confirm the 

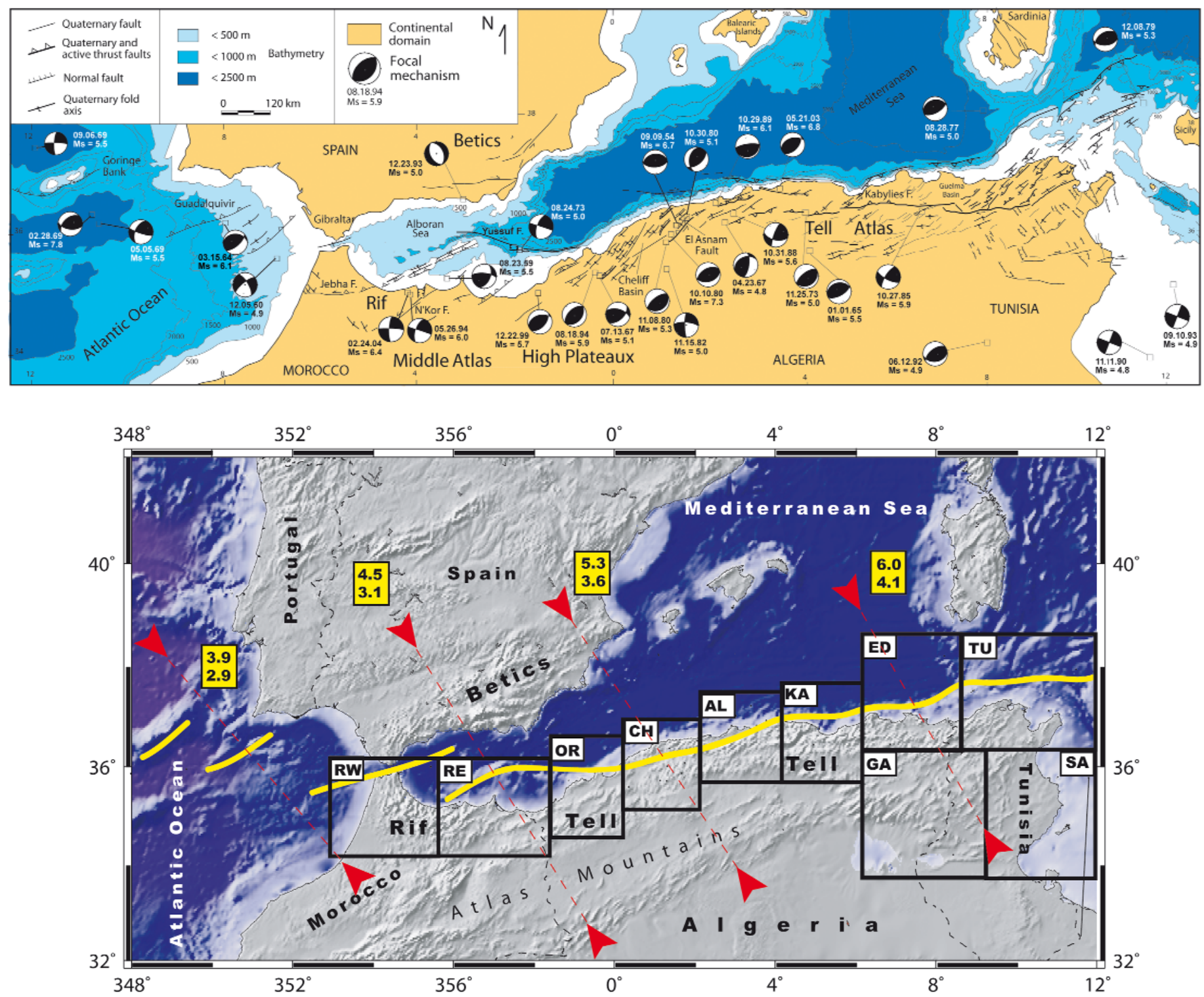

Figure 1. (a) Neotectonic and seismotectonic map along the Atlas mountains of North Africa [McKenzie 1972, Meghraoui et al. 1986, Dlala 1992, Rebai et al. 1992, Pondrelli et al. 1995, Meghraoui et al. 1996, Morel and Meghraoui 1996]. Quaternary tectonic structures characterize the recent compressional deformations along the plate boundary [Meghraoui 1988]. Focal mechanisms are CMTs [Dziewonski et al. 2000] of studied major seismic events in the Rif and Tell Atlas. (b) Definition of the 10 tectonic zones in the quadrants along the plate boundary, named as defined in the text and reported in Table 1: RW, Rif west; RE, Rif east; OR, Oran; CH, Cheliff; AL, Algiers; KA, Kabylia; ED, Edough; GA, Gafsa; TU, Tunis; SA, Sahel. The plate boundary is represented by the schematic yellow line (see also Figure 2c). The convergence directions from the global geodetic models (red arrows) with minimum and maximum convergence rates (yellow boxes) indicate an eastward increase [Nocquet and Calais 2004].

oblique convergence and associated rate from Gibraltar to Tunisia-Sicily (Figure 1b) [Fernandes et al. 2007, Serpelloni et al. 2010, Vernant et al. 2010]. In this context, the relationships between the dextral Gloria transform fault (west of Gibraltar) and the Atlas geological domain is comparable to the tectonic pattern of continental-collision belts, where the major transcurrent faults interact with thrustand-fold systems [Oldow et al. 1990, Frizon de Lamotte et al. 2000]. Using magnetic reversal reconstructions in the Atlantic, the onset of continent-continent convergence between Iberia and North Africa was determined to be at 25 Myr [Srivastava et al. 1990]. Evidence of active delamination at the lithospheric scale beneath the Alboran Sea suggests a complicated geodynamic model for this plate boundary, instead of a simple subduction during the Late Cenozoic [Seber et al. 1996].

In the present study, published tectonic data on shortening directions of Quaternary faulting and folding correlated with moment tensor summation of significant seismic events have allowed us to estimate local and regional deformation rates in North Africa. The crustal deformation is documented along the Atlas Mountains in terms of the displacement field, with strain partitioning largely controlled by plate motions. On the basis of some mechanical properties of shear zones, we propose a kinematic model of transpression and block rotation that accounts for the main tectonic processes along the plate boundary in North Africa. 


\section{Active deformation and strain rates}

\subsection{Active tectonics and transpression}

Mainly structured during the Alpine orogeny (Eocene to Miocene), the E-W-trending coastal Atlas Mountains of North Africa underwent major active deformation during the Quaternary. This region can be subdivided into 10 distinct tectonic zones, from west to east (Figure $1 \mathrm{~b}$ ):

1. The West Rif (Figure 1b, RW) and the related southern Gibraltar region, which are characterized by NE-SW-trending Pleistocene folding, strike-slip faults, and SW vergence of fold-and-thrust nappes [Chalouan et al. 2004].

2. The East Rif overthrust structures (Figure 1b, RE), with $S$ and $S W$ vergence, which are characterized by the two main NE-SW-trending, left-lateral, strike-slip faults (the Jebha and N'Kor faults), and related overthrust structures. These are also visible along the Alboran ridge anticlines that are limited to the north by the E-W-trending, right-lateral Yussuf fault [Morel and Meghraoui 1996, Ballesteros et al. 2008]. The two latter structures provide striking elements of recent tectonic activity, with regard to the late Quaternary deformation visible on seismic profiles across the Alboran Sea (i.e., folded and faulted Pleistocene and Holocene deposits along the ridge, and faulted young deposits with prominent topographic offset across the Yussuf pull-apart basin) [Chalouan et al. 1997]. This region was the site of the destructive 1994 and $2004 \mathrm{Al}$ Hoceima earthquakes [Stich et al. 2005, Cakir et al. 2006].

3. The Oran quadrant (Figure $1 \mathrm{~b}, \mathrm{OR}$ ) is the region where the marine Yussuf fault extends to the east into a large continental Neogene and Quaternary basin that is affected by the NE-SW-trending and right-stepped en-echelon active folds [Thomas 1976]. As the anticline axes are deformed in an 'S' shape, this suggests clockwise rotation during their growth. The 1790 large historical earthquake of Oran and the Mw 5.9 1999 Ain Temouchent earthquake resulted from the ongoing active deformation in this region [Belabbes et al. 2008].

4. The Cheliff region (Figure 1b, $\mathrm{CH}$ ) includes the NESW-trending and right-stepped en-echelon active folding of the Cheliff Basin and the associated El Asnam active fault responsible for the October 10, 1980, large earthquake (Mw 7.3) [Philip and Meghraoui 1983, Meghraoui et al. 1986].

5. The Algiers region (Figure 1b, AL) represents the intermontane sedimentary basins, which include the Mitidja, and shows an average of $1000 \mathrm{~m}$ of topographic offset, with strongly folded late Quaternary deposits [Maouche et al. 2011]. This area was the site of the last two large earthquakes with thrust mechanisms (Ms 6.4 of June 10, 1910, at Aumale, now Sour El Ghozlane, and Mw 6.8 of May 21, 2003, at Zemmouri-Boumerdes).

6. In the Kabylies (Figure 1b, KA), the high mountains of Djurdjura have thrusts and nappes and southern vergence that involves outcrops of basement rock, and they limit the Quaternary Soummam Basin and extend to the south to the High Plateau [Boudiaf et al. 1999]. This region was the site of numerous, although low to moderate, thrust earthquakes. The Beni Ourtilane thrust earthquake of November 10, 2000 (Mw 5.7) illustrates the active deformation in this region [Bouhadad et al. 2003].

7. The Edough Massif and the coastal region of northeast Algeria (Figure 1b, ED). The right-lateral, pull-apart Neogene and Quaternary basin of Guelma, and the left-lateral, NE-SW faults with the associated earthquakes (such as the October 27, 1985, Ms 5.9 earthquake at Constantine) [Meghraoui 1988] reflect the importance of tectonic movements in this region. Moreover, active folding and related thrusts observed offshore of the Algerian-Tunisian coastline mark the frontal limit of the convergent zone [Kherroubi et al. 2009].

8. The Gafsa region (Figure 1b, GA) that covers the Aures Mountains and the south Atlas limit with the Sahara platform in Algeria and Tunisia shows active folding and faulting and NNW-SSE-trending active graben structures. Moderate, but destructive, earthquakes have affected this area [Chihi 1995].

9. The Tunis region (Figure 1b, TU) extends eastwards across Tunisia. Active NE-SW, left-lateral and east-west striking, right-lateral faults with reverse components constitute the main tectonic framework [Ben Ayed 1986, Kassem 2004]. The Sicily-Tunisia zone with the E-Wtrending and NE-SW trending active thrusts are the main active zones in this region.

10. The Tunisian Sahel region (Figure $1 \mathrm{~b}, \mathrm{SA}$ ) is a poorly known zone that has moderate earthquakes with predominant strike-slip focal mechanisms. Uplifted marine terraces can be observed along the shorelines of this region [Chihi 1995].

Fault and fold structures, stress tensor inferred from tectonic features (in-situ measurements and fault-plane striations), and unconformities between Neogene and Quaternary sedimentary units in the Alboran back arc and the Cheliff intermontane basins provide evidence of NE-SW to NW-SE successive shortening movements superimposed on the main Cenozoic overthrust structures, [Meghraoui et al. 1986, Rebai et al. 1992]. Using restored cross-sections and detailed regional studies along the plate boundary zone across Spain and Morocco, Dewey and others [1989] estimated $5 \mathrm{~mm} / \mathrm{yr}$ for the N-S to NW-SE contractional rate over the last 9 Myr. Kinematic analysis of fault populations in the Rif and Tell Atlas indicates two successive shortening directions (NNE and then NNW), which suggests a clockwise block rotation of $15^{\circ}$ to $25^{\circ}$, if the main regional stress direction has remained unchanged since the early Quaternary [Meghraoui et al. 1986, Rebai et al. 1992, Morel and Meghraoui 1996]. Folded and faulted Quaternary deposits 

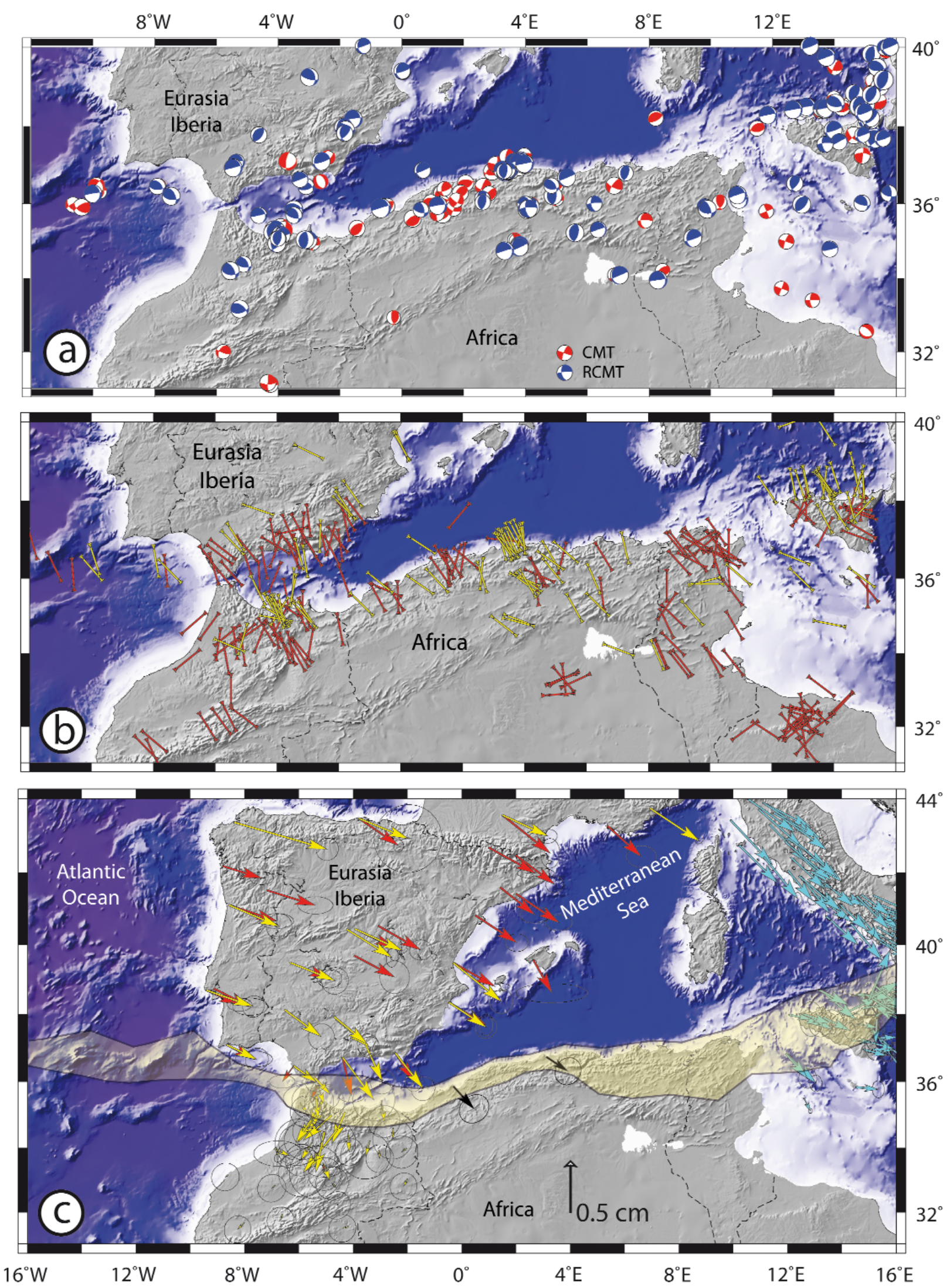

Figure 2. (a) Focal mechanism dataset used in the present study. Global CMTs in red and European Mediterranean RCMTs in blue (see main text for data references). (b) Quaternary tectonic shortening directions (red symbols) [Meghraoui 1988, Rebai et al. 1992, Morel and Meghraoui 1996] and P axes (yellow symbols) of all of the events mapped in Figure 2a for the dataset used in the present study. (c) Recent GPS data for the western Mediterranean with Nubia fixed (black, Anzidei et al. 2001; red, Fernandes et al. 2007; yellow, Vernant et al. 2010; cyan, Serpelloni et al. 2010). The yellow strip indicates the plate boundary zone in North Africa. A clockwise rotation of GPS directions can be observed from ENE-WSW in northern Iberia to NW-SE at the plate boundary in northern Algeria and N-S to ENE-SSW in northern Morocco. Note that the $P$ axes and shortening directions of Figure $2 \mathrm{~b}$ are not coincident with the convergence directions, as indicated by the GPS vectors in the western Mediterranean. This discrepancy is related to the obliquely convergent African and Eurasian plates. 
and marine terraces along the NE-SW, left-lateral faults of the Rif Mountains show uplift and left-lateral slip rates that reach a maximum of $1 \mathrm{~mm} / \mathrm{yr}$ and $2.3 \mathrm{~mm} / \mathrm{yr}$, respectively [Morel and Meghraoui 1996]. The late Pleistocene and Holocene shortening rate of $0.17 \mathrm{~mm} / \mathrm{yr}$ to $1.2 \mathrm{~mm} / \mathrm{yr}$ across the El Asnam fault was obtained from paleoseismic data analysis [Meghraoui and Doumaz 1996]. This implies an estimated total shortening rate that yields a maximum of $2.2 \mathrm{~mm} / \mathrm{yr}$ across the Tell Atlas, as obtained from summing the compressional deformation across the Cheliff basin and the related fault-related folds [Meghraoui et al. 1996]. The late Quaternary shortening directions obtained from the kinematic analysis of fault populations (Figure $2 \mathrm{~b}$ ) document the displacement field along the northern Atlas foldand-thrust belts, and indicate strain partitioning between the E-W, right-lateral, strike-slip faulting and the NE-SW, folding and thrust or reverse faulting. The comparison between the $P$ axis directions of the focal mechanisms, the shortening directions from fault kinematics, and the GPS slip directions and velocities indicate an along-strike difference in the shortening and compression directions (Figure $2 \mathrm{~b}$ and c). This discrepancy between local shortening and largescale convergence directions might be due to a transpression mechanism that expresses the interactions between the active folding and thrusting with the strike-slip faults along the plate boundary.

Local and regional seismotectonic studies in North Africa have suggested that the active thrusts and strike-slip faulting are coeval, and that contractional tectonics are accompanied by right-lateral en-echelon fold axes, basal décollements and dip-slip geometries with imbricate structures in the upper crust [Yielding et al. 1989, Meghraoui et al. 1996]. The correlation between the offshore, right-lateral Yussuf fault (of the Alboran Sea) and the continental rightstepping en-echelon folds in the Cheliff Basin (Figure 1a) implies that the crustal deformation is decoupled and therefore the E-W, right-lateral faults might be concealed beneath overthrust structures in western Algeria [Meghraoui 1988, Odonne and Costa 2003]. As also shown in Figure 1a, E-Wstriking, right-lateral, strike-slip faults with reverse components in the eastern Tell Atlas (e.g., the Kabylies fault) juxtapose basement rock and Quaternary sedimentary basins (e.g., the Guelma pull-apart basin). Although the seismotectonics in the Tell Atlas of Algeria is mainly expressed by NESW to E-W active thrust mechanisms, the E-W-trending, strike-slip mechanisms (e.g., in the Yussuf fault, Kabilies faults and Guelma basin) and the Quaternary folding represent the governing mechanisms along the plate boundary.

\subsection{Geodesy and convergence rate}

Recent measurements from GPS stations complement and increase the accuracy of recent tectonic movements of the previous global models of plate convergence of NUVEL-
1 and REVEL in the western Mediterranean [DeMets et al. 1994]. Early continuous GPS stations in northern Algeria installed in the framework of the Tyrrhenian Geodetic Network (TYRGEONET) and the Geodynamic Modeling of the Apennines (GEOMODAP) have provided results from measurements that extended from 1995 to 1998 from two stations in Algiers and Arzew [Anzidei et al. 2001] (see Figure 2c). The continuous GPS Geodynamic Data and Analysis Center (GEODAC) network with stations located mainly in Spain and Portugal, and three stations in northern Morocco, include the plate boundary between Iberia and Morocco. These data were processed from 1996 to 2005 and revealed a clear clockwise rotation of convergence rates from WNW-ESE in northern Spain, to NW-SE in southern Spain, and NNE-SSW in northern Morocco [Fernandes et al. 2007]. This rotation was further confirmed by survey-mode GPS campaigns from 1999 to 2009 in Morocco, which incorporated results from continuous GPS in Spain [Vernant et al. 2010, Koulali et al. 2011]. All of the GPS data indicated a $3 \mathrm{~mm} / \mathrm{yr}$ to $5 \mathrm{~mm} / \mathrm{yr}$ rate of convergence across the plate boundary between Spain and Algeria-Morocco regions, and $1 \mathrm{~mm} / \mathrm{yr}$ to $2 \mathrm{~mm} / \mathrm{yr}$ velocities in southern Spain and the Rif Mountains, and $2 \mathrm{~mm} / \mathrm{yr}$ to 3 $\mathrm{mm} / \mathrm{yr}$ across the Tell Atlas in Algeria. The rates of convergence increase to $5-6 \mathrm{~mm} / \mathrm{yr}$ further east across the plate boundary between Lampedusa, Sicily and Sardinia [Serpelloni et al. 2007] (Figure 2c). The change in the convergence directions shown by GPS data from the Gibraltar Strait to Sicily illustrates an obliquely convergent plate boundary.

\subsection{Seismicity and moment tensor summation}

The area that includes the fold-and-thrust belt of North Africa and Sicily has been characterized by the occurrence of several large and moderate shallow earthquakes (Figures 1a and 2a). The thrust focal mechanisms are predominantly located in the Tell Atlas (northern Algeria) and the right-lateral strike-slip mechanisms are mainly in the Atlantic and Alboran sea domains, which suggests the oblique convergence and an associated transpression system. Even if not homogeneous, the spread of shallow seismicity over the plate boundary and the recently well-constrained seismic parameters (such as focal mechanisms and seismic source characteristics) required the subdivision of the study region into 10 zones. The local and regional active tectonics combined with the characteristics of moderate and large earthquakes constrain the defined zones. The strain field distribution along the coastal Rif and Tell mountains has a general consistency with the $P$ axis directions of the focal mechanism solutions, which strike from NW-SE to N-S going eastwards (Figures $1 \mathrm{a}$ and $2 \mathrm{~b}$ ).

To study the pattern of seismic deformation along the plate boundary zone, we use the more recently updated dataset of moment tensors that is available for the last $30 \mathrm{yr}$ in this region (Figure 3). Moment tensors are obtained by merging all of the on-line catalogs: (1) the Global Centroid 


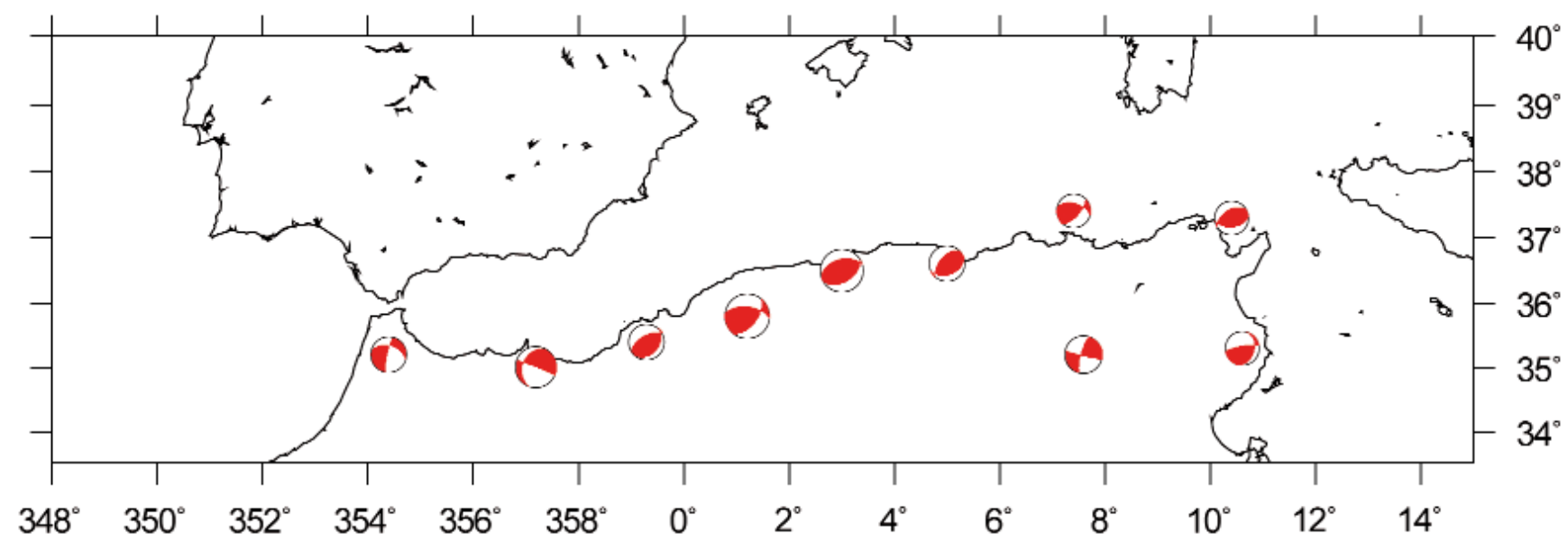

Figure 3. Composite focal mechanisms from the moment tensor summations, as computed for each tectonic zone defined in Figure $1 \mathrm{~b}$ [Pondrelli et al. 1995, Pondrelli 1999, Pondrelli et al. 2011]. Northwestern Algeria shows a consistent pattern of thrust mechanisms, in agreement with the Tell Atlas thrust-and-fold active belt. The seismic parameters are reported in Table 1.

Moment Tensor (GCMT) catalog [Dziewonski et al. 1983, 2000, and references therein; Ekström et al. 2005a, 2005b; www.globalcmt.org] that includes the seismic moment tensors for all earthquakes worldwide with $\mathrm{M} \geq 5.5$ available, starting from 1977; (2) the European Mediterranean Regional Centroid Moment Tensor (RCMT) catalog [Pondrelli et al. 2002, 2004, 2006, 2007; http: / /www.bo.ingv.it/RCMT] that includes the moment tensors for all seismic events with $M \geq 4.5$ in Europe and the Mediterranean region, starting from 1997. When a moment tensor exists in both catalogs, for a given earthquake with $M>5.5$, we select the GCMT, while for lower M we use the RCMT solution. As already used for similar datasets by Pondrelli et al. [2006], these criteria are associated with the methods used to compute the moment tensors. Indeed, GCMTs have been traditionally computed by inverting for body and mantle seismic waves, which are suitable for large-magnitude events, thus with $M>5.5$, while the RCMTs are computed by inverting for surface waves, that when recorded at regional distances are appropriate to determine the seismic moment tensor for moderate magnitude events, with $4.5>\mathrm{M}>5.5$.

The dataset that we composed and used in the computations included seismic moment tensors for earthquakes of the last 30 years with $\mathrm{M}>4.5$ (Figure 2). We applied the moment tensor summation technique to each box [Kostrov 1974, Jackson and McKenzie 1988, Ekström and England 1989, Westaway 1990], which allowed quantitative evaluation of the strain due to a number $\mathrm{N}$ of earthquakes within a rock volume V. V is commonly a layer characterized by a length, width and the thickness of the seismogenic zone, which is here fixed to $15 \mathrm{~km}$ (Table 1). The Kostrov [1974] methodology works starting from the following equation:

$$
\bar{\varepsilon}_{i j}=\frac{1}{2 \mu V} \sum_{k=1}^{N} M_{i j}^{k}
$$

where $\mu$ is the shear modulus, and the sum of the moment tensor elements $M_{i j}$ is taken for each $k$-earthquake. Already applied in the Mediterranean, this method evolved to determine the average strain rate integrated over time. In addition, we calculate the seismically inferred velocity and the percentage of seismic strain rate that can be compared to an expected strain rate determined with other data; e.g. geodetic measurements [Jackson and McKenzie 1988, Pondrelli et al. 1995, Meghraoui and Pondrelli 1998, Vannucci et al. 2004, Stich et al. 2006]. Using Equations (4) and (7) in Pondrelli et al. [1995] and with 30 years of data, we compute the relative horizontal velocities for each box, as normal $\left(\mathrm{v}_{\mathrm{xx}}\right)$ and parallel $\left(\mathrm{v}_{\mathrm{xy}}\right)$ to the plate boundary (the reference system being NE-down as positive, equal to xyz). To evaluate how much the seismic strain contributes to the total seismically inferred velocity at the plate boundary, we also computed the moment tensor rate $\mathbf{N}$ for each box [Jackson and McKenzie 1988, Pondrelli et al. 1995], which was determined on the basis of the NUVEL-1 velocities [DeMets et al. 1994]. The comparison between $\mathbf{N}$ and the cumulative seismic moment tensor rate gives the percentage of seismic deformation with respect to the overall deformation, and allows the definition of the aseismic deformation. Furthermore, our seismic strain results are strictly related to the volume of the boxes; e.g. the volume within which we average the seismic moment release. These boundary conditions are acceptable when the objective is only to obtain a picture of the seismic deformation pattern, while they become critical if we seek an absolute deformation rate.

Computations were carried out on separate boxes, to identify the partitioning of strain distribution and where strike-slip or compressive deformation prevails. The data are shown in Table 1, where all of the used and obtained parameters are reported for each box. In Figure 3, the cumulative focal mechanisms obtained by moment tensor summations show that when moving from $\mathrm{W}$ to $\mathrm{E}$, the geometry of the seismic deformation is different from what is expected for a pure compressive tectonic boundary. It is evident that the deformation is not simply purely compressive, and that a strike- 


\begin{tabular}{ccccccccccc}
\hline Box & $\begin{array}{c}\text { Length } \\
(\mathrm{km})\end{array}$ & $\begin{array}{c}\text { Width } \\
(\mathrm{km})\end{array}$ & $\begin{array}{c}\text { Predicted velocity } \\
(\mathrm{cm} / \mathrm{yr})\end{array}$ & Strike & $\begin{array}{c}\mathbf{N} . \\
\text { events }\end{array}$ & $\begin{array}{c}\text { Total seismic moment } \\
\left(\mathrm{e}^{25} \text { dyn.cm }\right)\end{array}$ & $\begin{array}{c}\mathbf{v}_{\mathbf{x x}} \\
(\mathrm{mm} / \mathrm{yr})\end{array}$ & $\begin{array}{c}\mathbf{v}_{\mathbf{x y}} \\
(\mathrm{mm} / \mathrm{yr})\end{array}$ & $\begin{array}{c}\mathbf{\% x x} \\
\mathbf{\% x y}\end{array}$ \\
\hline RE & 220 & 120 & 0.38 & 150 & 27 & 5.142 & -1.624 & 4.073 & 49 \\
RW & 250 & 120 & 0.35 & 120 & 6 & 0.229 & -0.098 & 0.358 & 6 & 214 \\
AL & 200 & 120 & 0.45 & 150 & 21 & 22.248 & -5.299 & 4.335 & 136 & 193 \\
CH & 200 & 120 & 0.45 & 150 & 13 & 54.815 & -9.668 & 14.349 & 248 & 638 \\
ED & 220 & 220 & 0.50 & 160 & 2 & 0.186 & -0.037 & 0.040 & 0.80 & 2.3 \\
GA & 300 & 300 & 0.50 & 160 & 6 & 0.881 & -0.062 & 0.437 & 1.3 \\
KA & 220 & 100 & 0.45 & 150 & 4 & 0.569 & -0.086 & 0.180 & 2.2 \\
OR & 200 & 120 & 0.38 & 150 & 2 & 0.513 & -0.054 & 0.204 & 1.6 \\
SA & 250 & 300 & 0.50 & 160 & 5 & 0.189 & 0.005 & 0.031 & 0.10 \\
TU & 300 & 200 & 0.50 & 160 & 2 & 0.148 & -0.025 & 0.021 & 0.5 \\
\hline
\end{tabular}

Table 1. Parameters obtained from the computation of the cumulative moment tensors. See Figure $1 \mathrm{~b}$ for each box and tectonic zone. The length and width are for the volume $\mathrm{V}$ used in the summation, with the strain rate predicted by the NUVEL-1 plate tectonic model [DeMets et al. 1994). $\mathrm{v}_{\mathrm{xx}}$ and $\mathrm{v}_{\mathrm{xy}}$ represent the seismically inferred velocity across $\left(\mathrm{v}_{\mathrm{xx}}\right)$ and along $\left(\mathrm{v}_{\mathrm{xy}}\right)$ the plate boundary, with the percentages of the seismic deformation with respect to the overall deformation across (\%xx) and along (\%xy) the boundary also given. The reference system used is $x$ corresponding to North-positive, $y$ corresponding to East-positive, and $z$ corresponding to down-positive.

slip component in most of the boxes prevails or provides a greater contribution, as for the Cheliff region (Figure 1b, $\mathrm{CH}$ ). This strain distribution is typical of oblique convergence, where part of the deformation is cumulating not only across it, but also along the strike of the boundary.

The geometry of the deformation pattern is confirmed also by the seismic velocity values and percentages (Table 1). Taking into account that the computations are carried out in a reference system where $\mathrm{x}$ is North-positive, $\mathrm{y}$ is East-positive and $z$ is down, we can see that in all of the studied regions the seismic velocity component across the boundary (Table $1, \mathrm{v}_{\mathrm{xx}}$ ) is compressive (negative values), which also reaches values of nearly $10 \mathrm{~mm} / \mathrm{yr}$ for the Cheliff region. The only opposite result is for the SA region (Tunisia; Figure 1a), where seismicity is relatively scarce, but extension in this region can exist. The greatest values are, however, found for the seismically inferred velocity component along the boundary $\left(\mathrm{v}_{\mathrm{xy}}\right)$, all of which are positive, which means dextral motion. In a couple of regions, the strike-slip component is greater than the compressive component, as in the East Rif and Cheliff regions. Areas with seismically inferred velocities $\left(\mathrm{v}_{\mathrm{xx}}\right.$ and $\left.\mathrm{v}_{\mathrm{xy}}\right)$ lower than $0.1 \mathrm{~mm} / \mathrm{yr}$ are not used in our discussion, although we take into account that they follow the general trend.

Comparing the predicted strain rate obtained using NUVEL-1, and the seismically inferred velocities computed in this study, we evaluate the ratio of total deformation inferred from the existing shallow seismicity. In three regions, the seismically inferred velocity is greater than that predicted. In particular, this is the case in the East Rif region, for the strike-slip component only, and in the Algiers and Cheliff regions, where the seismically inferred velocity is larger for both components. It is worth noting that for all of the regions, the percentages of the strike-slip motion are greater than the percentages of the predicted compressive strain rate. This implies that a considerable part of the strike-slip deformation is not accounted for along the North Africa plate boundary in the NUVEL-1 global plate motion model. Hence, these results underline how the strike-slip motion is relevant in an area where usually only the convergence is considered, and that the missed component of transpression and internal deformation along the plate boundary needs to be taken into account in the kinematic model.

Finally, the comparison between the $P$ axis directions of focal mechanisms, the shortening directions from fault kinematics, and the GPS velocities and directions indicates a clear along-strike difference (Figures $2 b$ and $c$ ). This discrepancy between the shortening and convergence directions might reflect a transpression mechanism with interactions between active folding and thrusting with strike-slip faults along the plate boundary.

\section{Model of block rotation and transpression}

In a previous study, analysis of recent tectonic structures of the Goringe-Alboran-Tell (GALTEL) regions revealed that the Quaternary fault-related folds and associated shallow seismicity can be interpreted as a transpressive deformation with clockwise block rotation [Morel and Meghraoui 1996]. Kinematic modeling with block rotations applied to the Transverse Ranges in California, USA [Jackson and Molnar 1990], provide an interesting analog to the North Africa plate boundary. For the sake of simplicity of the tectonic blocks in North Africa, we group these as: (i) the Rif in a single large block (Figure 1b, RE plus RW); (ii) Algiers and Kabylies in a single large block (Figure 1b, AL plus KA); and (iii) the Edough, Gafsa, Tunis and Sahel re- 


\begin{tabular}{lcccc}
\hline Zone & $\begin{array}{c}\text { Convergence rate } \\
(\mathrm{mm} / \mathrm{y})\end{array}$ & $\begin{array}{c}\phi \\
\left({ }^{\circ}\right)\end{array}$ & $\begin{array}{c}\theta \\
\left({ }^{\circ}\right)\end{array}$ & 2.24 \\
$\left({ }^{\circ} / \mathrm{Myr}\right)$ \\
Rif-Alboran & 3.6 & 35 & 40 & 3.62 \\
Cheliff west & 4.5 & 45 & 50 & 3.58 \\
Cheliff east & 4.5 & 45 & 55 & 3.27 \\
Kabylies & 5 & 35 & 60 & 3.9 \\
Tunisia-Sicily & 5 & 45 & 60 & 3.9 \\
\hline
\end{tabular}

Table 2. The clockwise rotation rates, $R$, calculated for the small tectonic blocks, and averaged for main tectonic zones along the North Africa plate boundary. See Figure $1 \mathrm{~b}$ and explanation in main text for the model of block rotation and transpression. Convergence rates and strikes $\theta$ are from NUVEL1 [DeMets et al. 1994], $\phi$ is the angle between the tectonic blocks and the trend of the deforming zone.

gions in a single large block (Figure 1b, ED, GA, TU plus $\mathrm{SA}$ ). The sub-division of the remaining five tectonic zones (see Figure $1 \mathrm{~b}$ and Table 2 ) is based on the active tectonics background and the known seismic fault parameters. Taking into account the main shock location, the coseismic faulting, and the aftershock distribution of the El Asnam earthquake [Yielding et al. 1989], we can delimit small tectonics blocks ( $50 \mathrm{~km}$ long, $20 \mathrm{~km}$ wide) that belong to a large zone and can undergo rotation (Figures $1 \mathrm{~b}$ and 4 ). This pattern of active deformation can be modeled and expressed by means of field parameters, as follows.

\subsection{Rotation}

The model assumes the rotation $R$ of small rigid blocks about the vertical axes and in a zone of continuous deformation [Lamb 1987], where:

$$
R=w / 2[(\cos 2 \phi-\operatorname{tg} \theta \sin 2 \phi)-1]
$$

The parameters of relation (2) include the strain rate $w=S v \cdot \cos \theta / a ; \theta$ as the angle between the direction of the slip rate vector $S v$ and the deforming zone; $a$ as the width of the deforming zone; and $\phi$ as the angle between the small block trend and the deforming zone (Figure 4). The block rotation implies a combined simple-shear and pureshear deformation if we consider pinned blocks, due to the local tectonic conditions (deformation strip along the plate boundary) [Jackson and Molnar 1990]. Although the constraints of rotation rates depend totally on the chosen convergence rate, the inferred clockwise rotation rates in the Rif and Tell Atlas presented in Table 2(2.24\% $/$ Myr to $3.9^{\circ} / \mathrm{Myr}$ ) are consistent with the data obtained from paleomagnetic analyses in the Caltanisetta basin (North African margin in Sicily) since the Pliocene $\left(3^{\circ} / \mathrm{Myr}\right.$ to $\left.7^{\circ} / \mathrm{Myr}\right)$ [Scheepers and Langereis 1993], and in the Cheliff basin near the El Asnam fault ( $3^{\circ} / \mathrm{Myr}$ to $8^{\circ} / \mathrm{Myr}$ ) [Aifa et al. 1992, Derder at al. 2011].
Bookshelf Model

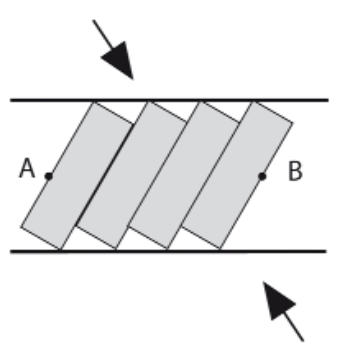

Pinned Model

(McKenzie \& Jackson, 1983) (Jackson \& Molnar, 1990)

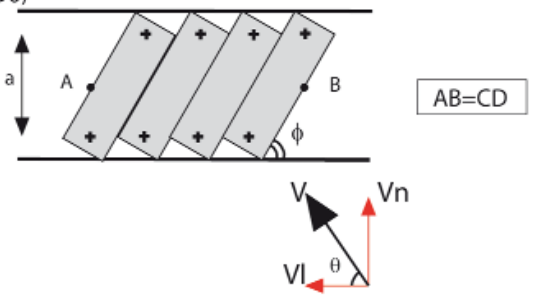

$\mathrm{AB}<\mathrm{CD}$ Compressed Area
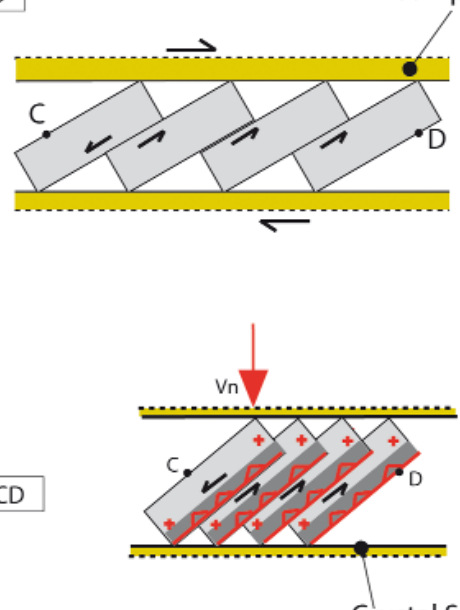

Crustal Shortening

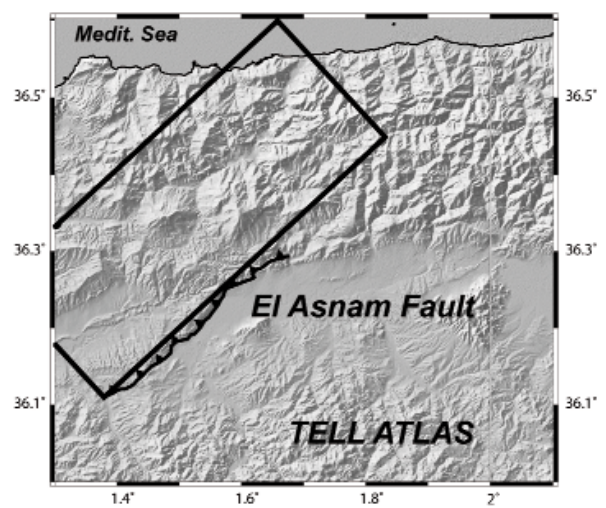

Figure 4. Upper panels: Kinematic model of a deformed zone with small-block rotation and lateral extension [Lamb 1987, Jackson and Molnar 1990]. Lower panels: pinned model where the slip vector $\mathrm{V}=\mathrm{Vn}+\mathrm{Vl}$ and with no lateral extension within the deforming zone. The difference between the bookshelf and pinned models is illustrated by the different distances of CD in each case. The shortening angle $\beta$ represents the ratio between the pure shear and lateral shear within the deforming zone, $\alpha$-1 represents the shortening across the zone, and $\theta$ is the convergence strike (see text). The shaded relief shows a schematic representation of a small tectonic block and the related El Asnam fault. The calculated compression-to-transcurrence ratios are given in Table 3. 


\subsection{Transpression}

In continuum mechanics, the transpression deformation can be factorized into simultaneous lateral displacements (simple shear) and horizontal shortening (pure shear). With $\alpha^{-1}=(1-S)$ representing the shortening across the zone, and $S$ as the amount of shortening, the shear strain,

$$
\gamma=\tan \phi=S /(1-S) \cot \beta
$$

can be expressed as a function of the contraction deformation [Sanderson and Marchini 1984]. The Quaternary shortening directions (Figure $2 \mathrm{~b}$ ), which can be expressed by the angle $\beta$ with respect to the zone margin, range from $140^{\circ} \mathrm{N}$ to $180^{\circ} \mathrm{N}$ along the North Africa plate boundary, and might result from the partitioning of transpressional strain (Figure 4) [Teyssier et al. 1995, Jones and Tanner 1995, Meghraoui and Pondrelli 1998]. Hence, the compression-to-transcurrence ratio that can be estimated at each point along the plate boundary is calculated from:

$$
\frac{\partial S}{\partial \gamma}=\frac{1}{\alpha^{2} \cot \beta}
$$

The shortening dimension $\alpha^{-1}=0.58$ is estimated from the $50 \mathrm{~km}$ of shortening during the last 9 Myr along the Tell and Rif Atlas [Dewey et al. 1989]. Taking into account an average value of $\beta$ for the five tectonic zones identified for the model of block rotation along the plate boundary, we obtain a compression-to-transcurrence ratio ranging between $33 \%$ at Gibraltar to $50 \%$ across northern Tunisia (see also Table 3 ).

\section{Pattern of deformation of the plate boundary: discussion and conclusions}

The plate boundary in North Africa is here examined in the light of the numerous detailed geological and seismological analyses. The quantitative estimation of the displacement field along the five zones of the Atlas Mountains indicates that as well as convergent movements, the right-lateral faulting mechanism observed on the Atlantic side also affects the crustal deformation in North Africa [Meghraoui and Pondrelli 1998, Pondrelli 1999, Gomez et al. 2000]. Although the shallow thrust mechanisms can be related to the crustal shortening by means of basal décollements, the convergent driving mechanism appears to be controlled at depth also by strike-slip and high-angle reverse faults. The model of transpression and block rotation that we propose is based on numerous and detailed observations along the plate boundary, where the pattern of deformation of active zones, such as the El Asnam region, is taken as a reference.

Field observations and analog experiments show that NE-SW-trending, active fault-related folds can be coeval with E-W, deep-seated, right-lateral, strike-slip faults, and refer to transpressional tectonics [Thomas 1976, Oldow et al. 1990, Odonne and Costa 2003]. The relationships between the two

\begin{tabular}{lcc}
\hline Zone & $\boldsymbol{\beta}(\mathbf{r a d})$ & $\begin{array}{c}(\mathbf{d} \mathbf{S} / \mathbf{d t}) /(\mathbf{d} \gamma / \mathrm{dt}) \\
(\%)\end{array}$ \\
\hline Rif-Alboran & 1.57 & 33 \\
Cheliff west & 0.99 & 43 \\
Cheliff east & 1.27 & 37 \\
Kabylies & 1.39 & 36 \\
Tunisia-Sicily & 0.78 & 50 \\
\hline
\end{tabular}

Table 3. Average strikes of the shortening component, $\beta$, with regard to the deforming zone, and derived compression-to-transcurrence ratios, $(\mathrm{dS} / \mathrm{dt}) /(\mathrm{d} \gamma / \mathrm{dt})$, along the plate boundary in North Africa. Note that the maximum compression-to-transcurrence ratios are obtained for the two main bends along the plate boundary: Cheliff west and Tunisia-Sicily.

faulting types can also be interpreted using a simple kinematic model that integrates clockwise block rotations within a deforming zone similar to that applied in the active Transverse Ranges in California (Figure 4) [Jackson and Molnar 1990]. The remarkable correlation between field observations [Meghraoui et al. 1986, Meghraoui et al. 1996, Morel and Meghraoui 1996] and paleomagnetic data [Aifa et al. 1992, Scheepers and Langereis 1993] reinforces the idea that our model of clockwise small-block rotation is not speculative, but is supported by the tectonic and seismological data. The plate boundary in North Africa can be considered as a narrow E-W-trending zone, with dextral shearing and contractional deformation.

The deformation zone in Figure 2c (yellow strip) shows that the plate boundary does not have a linear shape, but instead a rather irregular strip with three main bends, in the Alboran Sea, the Cheliff Basin, and the Sicily-Tunisia domain (Figure 5). This deformation zone encompasses from the eastern end of the Gloria Transform to Sicily, and it is defined by the occurrence of large earthquakes with $\mathrm{Mw} \geq 6.0$. The two latter bends, the Cheliff Basin and the SicilyTunisia domain, correspond to zones of maximum compression-to-transcurrence ratio (Table 3, 43\% and 50\%, respectively), which are in agreement with the eastward rotation from $120^{\circ} \mathrm{N}$ to $170^{\circ} \mathrm{N}$ of the convergence directions, and implies that the compression-to-transcurrence ratio increases progressively eastwards (Figures $2 \mathrm{c}$ and 5). Taking into account the $P$ axes directions of significant earthquakes along the Gibraltar-Sicily plate boundary and the shortening directions from the tectonic data (Figure $2 \mathrm{~b}$ ), there is good correlation when only the Quaternary thrust structures and the focal mechanisms are involved. A more complex tectonic picture appears for the Alboran-Rif region, which might be due to a rapidly changing deformation zone and the superposition of successive tectonic phases. However, the occurrence of the 1959 (Ms 5.5) Yussuf earthquake and the 1994 and 2004 (Mw 6.0, Mw 6.4, respectively) Al Hoceima earthquakes, and the related Quaternary tectonic 


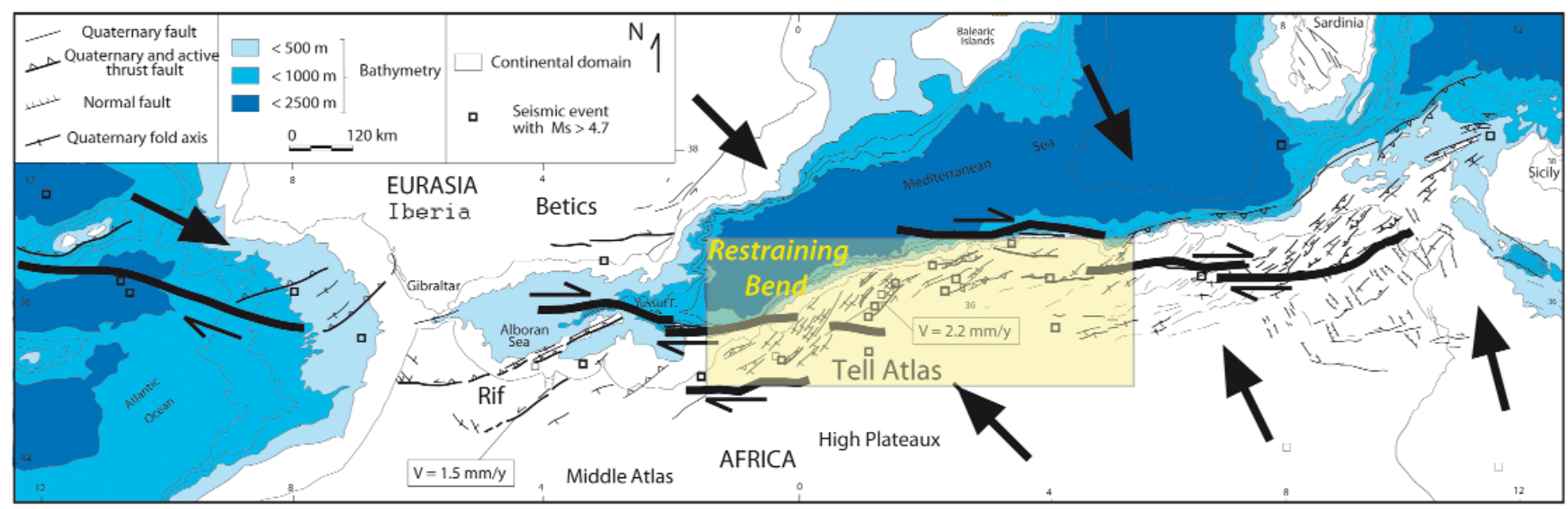

Figure 5. Map showing the plate boundary as a narrow E-W-striking, right-lateral deforming zone that limits the left-lateral, NE-SW-trending faults (see also block rotations in Figure 4). Large arrows indicate convergence plate directions according to the GPS vectors in northern Iberia, southern Morocco and southern Sicily-Lampedusa [Anzidei et al. 2001, Fernandes et al. 2007, Serpelloni et al. 2010, Vernant et al. 2010]. The oblique convergence implies an eastwards increase in the contractional-to-trancurrence ratio (see also Tables 2 and 3). The oblique convergence and geometry of the deforming zone at the plate boundary indicates an area (shaded) of restraining bend with significant transpressive deformation, which corresponds to the zone of the greatest earthquake activity in North Africa. V is the local shortening rate.

structures, provide a clearer view of the active deformation in the region. When compared with the pattern of active faulting and the distribution of shortening directions (Figure $2 b$ and $c$ ), the clockwise rotation of GPS velocities is predominant at the boundary between the Betics in Spain and Rif in Morocco (Figure 2c). The discrepancy between the $P$ axes of the earthquake focal mechanisms and the GPS directions allows us to consider the Rif and Tell Atlas belt as a deformation strip along the North Africa plate boundary. This difference in the convergence directions is the result of an obliquely convergent plate boundary.

The regional strain partitioning in North Africa is inferred from the interactions between folds and strike-slip faults in a deforming zone. Although the role of strike-slip faulting is difficult to integrate into a convergent model of the plate boundary, its geometry and relationships to the active thrust or reverse fault are here illustrated by the bookshelf and pinned-block model of Figure 4. The angular difference between the shortening directions and the convergence is significant here, where the plate boundary is oblique to the convergent motion; i.e., the discrepancy between shortening and convergence is more evident along the western section of the plate boundary (see Figure 2). In this case, the shortening component is refracted from the slip vectors along the $\mathrm{E}-\mathrm{W}$-trending plate boundary and it cannot be considered as coaxial with the convergence direction. Furthermore, the left-stepping geometry of the deforming zone in northwest Algeria and along the plate boundary can be interpreted as a restraining bend with significant transpressive deformation (Figure 5). This is supported by the occurrence of the largest earthquakes of the plate boundary in the Rif and Tell Atlas $(M>6.0)$.

The velocities computed from the seismic deformation (Table 1) are clearly higher than the predicted velocities obtained from the global plate motion models (NUVEL-1A), an observation that is more pronounced on the strike-slip component than on the compressive values. Moreover, as the percentages of transpressive motion are always greater than the compressive components, this implies that the NUVEL-1 results used to compute the predicted velocities do not include at least part of the deformation along the boundary. This unexpected amount and style of Quaternary deformation can be attributed to strain that is produced within the boundary by the block rotation modeling proposed herein. The seismic deformation evaluated in this study takes place over a time span that is probably not representative of the seismic cycle for the area, but it is significant for the recent large and moderate-sized events that occurred in the region. The $3 \mathrm{~mm} /$ yr to $5 \mathrm{~mm} / \mathrm{yr}$ geodetic convergence rate [Nocquet and Calais 2004] is, however, comparable with the estimated $1.5 \mathrm{~mm} / \mathrm{yr}$ and $2.2 \mathrm{~mm} / \mathrm{yr}$ [Meghraoui et al. 1996] across the active structures of the Rif and Tell Atlas, respectively. Furthermore, considering that the active deformation is distributed as far as the southern Sahara Atlas front, the estimated $2.2 \mathrm{~mm} / \mathrm{yr}$ is a lower bound of the total shortening rate along the plate boundary.

Acknowledgements. This work is dedicated to Renato Funiciello, for his constant support and encouragement. We are grateful to E. Boschi, D. Pantosti, P. M. de Martini, L. Sagnotti, and M. Anzidei for fruitful discussions about the plate boundary in southern Italy and North Africa. We thank R. M. Fernandes, P. Vernant and E. Serpelloni for sharing GPS data. M. M. is thankful to J. Andrieux, J. L. Morel, D. F. de Lamotte and F. Gomez for their comments and suggestions on the Atlas Mountains neotectonics. We thank F. Rossetti and two anonymous reviewers for their comments. Some of the maps were prepared using the Generic Mapping Tool software [Wessel and Smith 1998].

\section{References}

Aifa, T., H. Feinberg, M. Derder and N. Merabet (1992). Rotations paleomagnetiques récentes dans le bassin du Cheliff (Algerie), C. R. Acad. Sci., Paris, 314, 915-922. 
Anzidei, M., P. Baldi, G. Casula, A. Galvani, E. Mantovani, A. Pesci, F. Riguzzi and E. Serpelloni (2001). Insights into present-day crustal motion in the central Mediterranean area from GPS surveys, Geophys. J. Int., 146, 98-110.

Ballesteros, M., J. Rivera, A. Munoz, A. Munoz-Martın, J. Acosta, A. Carbo and E. Uchupi (2008). Alboran Basin, southern Spain - Part II: Neogene tectonic implications for the orogenic float model, Marine Petrol. Geol., 25, 75 101.

Belabbes, S., M. Meghraoui, Z. Cakir and Y. Bouhadad (2008). InSAR analysis of a blind thrust rupture and related active folding: the 1999 Ain Temouchent earthquake (Mw 5.7, Algeria) case study, J. Seismol.; doi:10.1007s109 50-008-9135-x.

Ben Ayed, N. (1986). Evolution tectonique de l'avant-pays de la chaîne alpine de Tunisie du début du Mésozoïque à l'Actuel. Thèse Doct. Ès-Sciences Naturelles, Univ. ParisSud Orsay, 286 pp.

Boudiaf, A., H. Philip, A. Coutelle and J.F. Ritz (1999). Découverte d'un chevauchement d'âge quaternaire au Sud de la grande Kabylie (Algérie), Geodynamica acta (Paris) 12 (2), 71-80.

Bouhadad, Y., A. Nour, N. Laouami and D. Belhai (2003). The Beni-Ourtilane-Tachaouaft fault and seismotectonic aspects of the Babors region (NE of Algeria), J. Seismology 7 (1), 79-88; doi:10.1023/ A:1021259931865.

Braunmiller, J., and F. Bernardi (2005). The 2003 Boumerdes, Algeria earthquake: regional moment tensor analysis, Geophys. Res. Lett. 32, L06305; doi:10.1029/2004GL022038.

Buforn, E., M. Bezzeghoud, A. Udias and C. Pro (2004). Seismic Sources on the Iberia - African Plate Boundary and their Tectonic Implications, Pure Appl. Geophys., 161, 124.

Cakir, Z., M. Meghraoui, A.M. Akoglu, N. Jabour, S. Belabbes and L. Ait-Brahim (2006). Surface deformation associated with the $M_{w}$ 6.4, 24 February 2004 Al Hoceima, Morocco, earthquake deduced from InSAR; implications for the active tectonics along North Africa, Bull. Seism. Soc. Am., 96, 59-68.

Chalouan, A., R. Saji, A. Michard and A.W. Bally (1997). Neogene Tectonic Evolution of the Southwestern Alboran Basin as Inferred from Seismic Data off Morocco, AAPG Bull., 81, 1161-1184.

Chalouan, A., and A. Michard (2004). The Alpine Rif Belt (Morocco): A case of mountain building in a SubductionSubduction-Transform Fault Triple Junction, Pure appl. geophys., 161, 489-519.

Chihi, L. (1995). Les fossés néogènes à quaternaire de la Tunisie et de la mer pélagienne: étude structurale et leurs signification dans le cadre géodynamique de la méditerranée centrale, Doctorat d'état des sciences géologiques, Université de Tunis, 566 pp.

D'Agostino, N., and G. Selvaggi (2004). Crustal motion along the Eurasia-Nubia plate boundary in the Calabrian Arc and Sicily and active extension in the Messina Straits from GPS measurements, J. Geophys. Res., 109, B11402; doi:10.1029/2004JB002998.

DeMets, C., R.G. Gordon, D.F. Argus and S. Stein (1994). Effect of recent revisions to the geomagnetic reversal time scale on estimates of current plate motions, Geophys. Res. Lett., 21, 2191-2194.

Derder, M.E.M., B. Henry, M. Amenna, B. Bayou, S. Maouche, J. Besse, A. Abtout, H. Boukerbout, M. Bessedik, S. Bourouis and M. Ayache (2011). Tectonic evolution of the active Chelif Basin (Northern Algeria) from paleomagnetic and magnetic fabric investigations, In: U. Schattner (ed.), New Frontiers in Tectonic Research - At the Midst of Plate Convergence, pp. 3-26; ISBN 978-953-307-594-5.

Dewey, J.F., M.M.L. Helman, E. Turco, D.H.W. Hutton and S.D. Knott (1989). Kinematics of the western Mediterranean, In: M. Coward (ed.), Alpine Tectonics, Spec. Publ. Geol. Soc. Lond., 45, 265-283.

Dlala, M. (1992). Seismotectonics study in northern Tunisia, Tectonophysics, 209, 171-174.

Dziewonski, A.M., A. Friedman, D. Giardini and J.H. Woodhouse (1983). Global seismicity of 1982: Centroid Moment Tensor solutions for 308 earthquakes, Phys. Earth Planet. Inter., 53, 17-45.

Dziewonski, A.M, G. Ekström and N.N Maternovskaya (2000). Centroid-moment tensor solutions for OctoberDecember, 1999, Phys. Earth Planet. Inter., 121 (3-4), 205 221.

Ekström, G., and P. England (1989). Seismic strain rates in regions of distributed continental deformation, J. Geophys. Res., 94, 10231-10257.

Ekström, G., A.M. Dziewonski, N.N. Maternovskaya, M. Nettles (2005a). Global seismicity of 2002: centroid-moment-tensor solutions for 1034 earthquakes, Phys. Earth Planet. Inter., 148, 303-326.

Ekström, G., A.M. Dziewonski, N.N. Maternovskaya, M. Nettles (2005b). Global seismicity of 2003: centroid-moment-tensor solutions for 1087 earthquakes, Phys. Earth Planet. Inter., 148, 327-351.

Faccenna, C., C. Piromallo, A. Crespo Blanc, L. Jolivet and F. Rossetti (2004). Lateral slab deformation and the origin of the western Mediterranean arcs, Tectonics, 23, TC1012; doi:10.1029/2002TC001488.

Fernandes, R.M.S., J.M. Miranda, B.M.L. Meijninger, M.S. Bos, R. Noomen, L. Bastos, B.A.C. Ambrosius and R.E.M. Riva (2007). Surface velocity field of the IberoMaghrebian segment of the Eurasia-Nubia Plate boundary, Geophys. J. Int., 169 (1), 315-324.

Frizon de Lamotte, D., B. Saint Bezar, R. Bracene and E. Mercier (2000). The two main steps of the Atlas building and geodynamics of the western Mediterranean, Tectonics, 19, 740-761. 
Gomez, F., W. Beauchamp and M. Barazangi (2000). Role of the Atlas Mountains (Northwest Africa) within the African-Eurasian plate-boundary zone, Geology, 28, 775778.

Grimison, N.L., and W. Chen (1986). The Azores-Gibraltar plate boundary: focal mechanisms, depth of earthquakes and their tectonic implications, J. Geophys. Res., 91, 20292047.

Jackson, J., and D. McKenzie (1988). The relationship between plate motions and seismic moment tensors, and the rates of active deformation in the Mediterranean and Middle East, Geophys. J. Int., 93, 45-73.

Jackson, J., and P. Molnar (1990). Active faulting and block rotations in the western Transverses Ranges, California, J. Geophys. Res., 95, 22073-22087.

Jones, R.R., and P.W.G. Tanner (1995). Strain partitioning in transpression zones, J. Struct. Geol., 17 (6), 793-802.

Kassem, J. (2004). Etude sismotectonique et évaluation de l'Aléa sismique régional au Nord-Est de la Tunisie: apport de la sismique réflexion dans l'identification des sources sismogénique, Thèse de doctorat en géologie Université de Tunis, $168 \mathrm{pp}$.

Kherroubi, A., J. Déverchère, A. Yelles, B. Mercier de Lépinay, A. Domzig, A. Cattaneo, R. Bracène, V. Gaullier and D. Graindorge (2009). Recent and active deformation pattern off the easternmost Algerian margin, Western Mediterranean Sea: New evidence for contractional tectonic reactivation, Marine Geology, 261, 17-32.

Kostrov, V. (1974). Seismic moment and energy of earthquakes, and seismic flow of rock, Izv. Acad. Sci. USSR Phys. Solid Earth, 1, 23-44.

Koulali, A., D. Ouazar, A. Tahayt, R.W. King, P. Vernant, R.E. Reilinger, S. McClusky, T. Mourabit, J.M. Davila, N. Amraoui (2011). New GPS constraints on active deformation along the Africa-Iberia plate boundary, Earth and Planetary Science Letters, 308, 211-217.

Lamb, S.H. (1987). A model for tectonic rotations about a vertical axis, Earth and Planet. Sci. Lett., 84, 75-86.

Maouche, S, M. Meghraoui, C Morhange and S. Belabbes, Y. Bouhadad and H. Haddoum (2011). Active coastal thrusting and folding, and uplift rate of the Sahel Anticline and Zemmouri earthquake area (Tell Atlas, Algeria), Tectonophysics, 509, 69-80.

McClusky, S., R. Reilinger, S. Mahmoud, D. Ben Sari and A. Tealeb (2003). GPS constraints on Africa (Nubia) and Arabia plate motions, Geophys. J. Int., 155, 126-138.

McKenzie, D.P. (1972). Active tectonics of the Mediterranean region, Geophys. J. R. Astr. Soc., 30, 109-185.

McKenzie, D.P., and J. Jackson (1983). The relationship between strain rates, crustal thickening, paleomagnetism, finite strain and fault movements within a deforming zone, Earth Planet. Sci. Lett., 65, 182-202.

Meghraoui, M., A. Cisternas and H. Philip (1986). Seismo- tectonics of the lower Chéliff basin: structural background of the El Asnam (Algeria) earthquake, Tectonics, 5 (6), 809-836.

Meghraoui, M. (1988). Géologie des zones sismiques du nord de l'Algérie Paléosismologie,Tectonique active et synthèse sismotectonique, $\mathrm{PhD}$ Thesis, Université de $\mathrm{XI}$, Centre d'Orsay (France), $356 \mathrm{pp}$.

Meghraoui, M., and F. Doumaz (1996). Earthquake-induced flooding and paleoseismicity of the El Asnam (Algeria) fault-related fold, J. Geophys. Res., 101, 17617-17644.

Meghraoui, M., J.L. Morel, J. Andrieux and M. Dahmani (1996). Tectonique plio-quaternaire de la chaîne tello-rifaine et de la Mer d'Alboran, Bull. Soc. Geol. France, 167, 143-159.

Meghraoui, M., and S. Pondrelli (1998). Transpression and block rotation along the plate boundary in North Africa, European Geophysical Society meeting, Nice, abstract.

Meghraoui, M., S. Maouche, B. Chemaa, Z. Cakir, A. Aoudia, A. Harbi, P.-J. Alasset, A. Ayadi, Y. Bouhadad and F. Benhamouda (2004). Coastal uplift and thrust faulting associated with the $\mathrm{Mw}=6.8$ Zemmouri (Algeria) earthquake of 21 May, 2003, Geophys. Res. Lett., 31, L19605; doi:10.1029/2004GL020466.

Morel, J.L., and M. Meghraoui (1996). The Goringe-AlboranTell (Galtel) tectonic zone: A transpression system along the Africa-Eurasia plate boundary, Geology, 24, 755-758.

Nocquet, J.M., and E. Calais (2004). Geodetic measurements of crustal deformation in the western Mediterranean and Europe, Pure Appl. Geophys., 161, 661-681; doi 10.1007/ s00024-003-2468-Z.

Odonne, F., and E. Costa (2003). Relationships between strike-slip movement and fold trends in thin-skinned tectonics: Analogue models, Tectonophysics, 228 (3-4), 383391.

Oldow, J.S., A.W. Bally and H.G. Ave-Lallement (1990). Transpression, orogenic float, and lithospheric balance, Geology, 18, 991-994.

Philip, H., and M. Meghraoui (1983). Structural analysis and interpretation of the surface deformation of the El Asnam earthquake of October 10, 1980, Tectonics 2, 1749.

Pondrelli, S., A. Morelli and E. Boschi (1995). Seismic deformation in the Mediterranean area estimated by moment tensor summation, Geophys. J. Int., 122, 938-952.

Pondrelli, S. (1999). Pattern of seismic deformation in the Western Mediterranean, Annali di Geofisica, 42, 57-70.

Pondrelli, S., A. Morelli, G. Ekström, S. Mazza, E. Boschi and A.M. Dziewonski (2002). European-Mediterranean regional centroid-moment tensors: 1997-2000, Phys. Earth Planet. Int., 130, 71-101.

Pondrelli, S., A. Morelli and G. Ekström (2004). EuropeanMediterranean Regional Centroid Moment Tensor catalog: solutions for years 2001 and 2002, Phys. Earth Planet. 
Int., 145 (1-4), 127-147.

Pondrelli, S., S. Salimbeni, G. Ekström, A. Morelli, P. Gasperini and G. Vannucci (2006). The Italian CMT dataset from 1977 to the present, Phys. Earth Planet. Int., 159 (3-4), 286-303; doi:10.1016/j.pepi.2006.07.008.

Pondrelli, S., S. Salimbeni, A. Morelli, G. Ekström and E. Boschi (2007). European-Mediterranean Regional Centroid Moment Tensor catalog: Solutions for years 2003 and 2004, Phys. Earth Planet. Int., 164 (1-2), 90-112.

Pondrelli, S., S. Salimbeni, A. Morelli, G. Ekström, L. Postpischl, G. Vannucci and E. Boschi (2011). EuropeanMediterranean Regional Centroid Moment Tensor Catalog: solutions for 2005-2008, Phys. Earth Planet. Int., 185 (3-4), 74-81.

Rebai, S., H. Philip and A. Taboada (1992). Modern tectonic stress field in the Mediterranean region: evidence for variation in stress directions at different scales, Geophys. J. Int., 110, 106-140.

Sanderson, D.J., and W.R.D. Marchini (1984). Transpression, J. Struct. Geol., 6, 449-458.

Scheepers, P.J., and C.G. Langereis (1993). Analysis of NRM directions from the Rosello composite: implications for tectonic rotations of the Caltanisetta basin, Sicily, Earth and Planet. Sci. Lett., 119, 243-258.

Seeber, D., M. Barazangi, A. Ibenbrahim and A. Demnati (1996). Geophysical evidence of lithospheric delamination beneath the Alboran sea and Rif-Betic mountains, Nature, 379, 785-790.

Sella, G.F., T.H. Dixon and A. Mao (2002). REVEL: a model for recent plate velocities from space geodesy, J. Geophys. Res., 107 (B4); doi:10.1029/2000JB000033.

Serpelloni, E., G. Vannucci, S. Pondrelli, A. Argnani, G. Casula, M. Anzidei, P. Baldi and P. Gasperini (2007). Kinematics of the western Africa Eurasia plate boundary from focal mechanisms and GPS data, Geophys. J. Int., 169 (3), 1180-1200; doi:10.1111/j.1365-246X.2007.03367.x.

Serpelloni, E., R. Bürgmann, M. Anzidei, P. Baldi, B. Mastrolembo Ventura and E. Boschi (2010). Strain accumulation across the Messina Straits and kinematics of Sicily and Calabria, from GPS data and dislocation modeling, Earth and Planet. Sci. Letters, 298, 347-360.

Srivastava, S.P., H. Schouten, W.R. Roest, K.D. Klitgord, L.C. Kovacs, J. Verhoef and R. Macnab (1990). Iberian plate kinematics: a jumping plate boundary between Eurasia and Africa, Nature, 344, 756-759.

Stich, D., F. Mancilla, D. Baumont and J. Morales (2005). Source analysis of the Mw 6.32004 Al Hoceima earthquake (Morocco) using regional apparent source time functions, J. Geophys. Res., 110, B06306; doi:10.1029/2004 JB003366.

Stich, D., E. Serpelloni, F. Mancilla and J. Morales (2006). Kinematics of the Iberia-Maghreb plate contact from seismic moment tensors and GPS observations, Tectonophysics,
426 (3-4), 295-317; doi:10.1016/j.tecto.2006.08.004.

Teyssier, C., B. Tikoff and M. Markley (1995). Oblique plate motion and continental tectonics, Geology, 23, 447-450.

Thomas, G. (1976). Mise en évidence de décrochements dextres Est-Ouest d'âge Quaternaire en Algérie Nord occidentale, C. R. Acad. Sc. Paris, 283, D, 893-896.

Vannucci, G., S. Pondrelli, A. Argnani, A. Morelli, P. Gasperini and E. Boschi (2004). An Atlas of Mediterranean seismicity, Annals of Geophysics, 47 (1), 247-306.

Vernant, Ph., A. Fadil, T. Mourabit, D. Ouazar, A. Koulali, J.M. Davila, J. Garate, S. McClusky and R. Reilinger (2010). Geodetic constraints on active tectonics of the Western Mediterranean: Implications for the kinematics and dynamics of the Nubia-Eurasia plate boundary zone, J. Geodynamics, 49, 123-129.

Wessel, P., and H.F. Smith (1998). New, improved version of 538 the generic mapping tools released, Eos Trans AGU, 539, 79-579; doi:10.1029/98EO00426.

Westaway, R. (1990). Present-day kinematics of the plate boundary zone between Africa and Europe, from the Azores to the Aegean, Earth and Planet. Sci. Letters, 96 (3-4), 393-406.

Yielding, G., M. Ouyed, G. King and D. Hatzfeld (1989). Active tectonics of the Algerian Atlas mountains, evidence from aftershocks of the $1980 \mathrm{El}$ Asnam earthquake, Geophys. J. Int., 99, 761-788.

Zitellini, N., E. Gràcia, L. Matias, P. Terrinha, M.A. Abreu, G. DeAlteriis, J.P. Henriet, J.J. Dañobeitia, D.G. Masson, T. Mulder, R. Ramella, L. Somoza and S. Diez (2009). The quest for the Africa-Eurasia plate boundary west of the Strait of Gibraltar, Earth and Planet. Sci. Letters, 280 (14), $13-50$.

\footnotetext{
${ }^{\star}$ Corresponding author: Mustapha Meghraoui, Institut de Physique du Globe de Strasbourg (UMR 7516), Strasbourg, France; email: m.meghraoui@unistra.fr.
}

(C) 2012 by the Istituto Nazionale di Geofisica e Vulcanologia. All rights reserved. 